\title{
GAMBARAN KADAR HbCO DALAM DARAH PADA MASYARAKAT DUSUN DEMELING, GEDANGAN, SIDOARJO
}

Devita Rahmah Pratiwi, Hadi Suryono, Demes Nurmayanti

\begin{abstract}
ABSTRAK
Carbon monoxide (CO) is one of the toxic pollutants which is resulted from the emission of mobile sources and immovable sources. The inhaled $\mathrm{CO}$ will go into the lungs then into the bloodstrea. For instance, it will compete with oxygen to bind the hemoglobin. CO-hemoglobin bond forms hemoglobin carboxy ( $\mathrm{HbCO}$ ) which is 200-300 times stronger than the oxygen bond with $\mathrm{Hb}$. As consequence, oxygen is pushed out from its bond with $\mathrm{Hb}$. This study aims to determine the description of blood HbCO levels in the community of Demeling Hamlet due to $\mathrm{CO}$ exposure from roads located in Gedangan and cooking oil factory nearby.

This research is descriptive research with cross sectional approach. Samples of $\mathrm{HbCO}$ in blood were taken from 12 housewives aas respondets who domiciled in Dusun Demeling and samples of $\mathrm{CO}$ in the air (5 points). Technique of sampling in this study used technique of Purposive Sampling. Data collected is analyzed using tabulation descriptively in the form of tables.

The results showed that $\mathrm{HbCO}$ levels in the blood of respondents living nearby Gedangan had an average of $9.98 \%$ and respondents living close to the cooking oil factory with an average of $8.68 \%$. Average of ambient CO levels in the air around Gedangan was $11456.04 \mu \mathrm{g} / \mathrm{Nm} 3$ and area near the cooking oil factory was $2063.07 \mu \mathrm{g} / \mathrm{Nm} 3$. Respondents aged > 40 years had an average $\mathrm{HbCO}$ in blood of $11.54 \%$ and the age of $\leq 40$ years had an average of 6.24\%.Respondents living> 5 years had an average $\mathrm{HbCO}$ of $9.34 \%$. Respondents whose location near Gedangan roads had average HbCO levels higher than respondents near the cooking oil factory because motor vehicle activity lasts for 24 hours. At last, to reduce CO content in the ambient air, it is hoped that people can create green environment by planting plants around their house.
\end{abstract}

Keywords $\quad$ : HbCO content, Carbon monoxide, Road

\section{PENDAHULUAN}

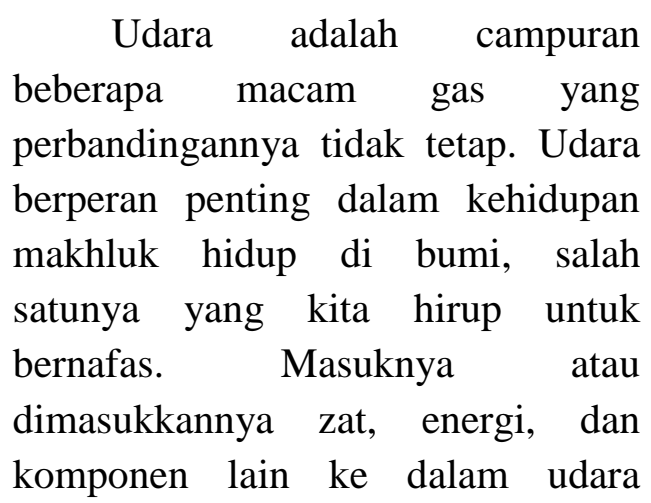

karena kegiatan manusia yang menyebabkan mutu udara turun serta tidak memenuhi fungsinya seperti sebagaimana mestinya, yang demikian itu disebut pencemaran udara. Pencemaran udara merupakan masalah lingkungan global yang terjadi di seluruh belahan dunia.

Udara bersih yang kita hirup merupakan gas yang tidak tampak, 
tidak berbau, tidak berwarna maupun berasa. Akan tetapi udara yang benar-benar bersih sudah sulit diperoleh, terutama di kota besar yang banyak industrinya dan padat lalu lintasnya. Udara yang tercemar dapat merusak lingkungan dan kehidupan manusia. Terjadinya kerusakan lingkungan berarti berkurangnya/rusaknya daya dukung alam yang selanjutnya akan mengurangi kualitas hidup manusia (Wardhana, 2004).

Pencemaran udara bersumber dari proses alami dan aktifitas manusia. Pencemaran dari proses alami dapat bersumber dari aktifitas alam seperti letusan gunung berapi, vegetasi, dan kebakaran hutan. Sedangkan pencemaran dari aktifitas manusia bersumber dari emisi sumber bergerak dan emisi sumber tidak bergerak. Kebanyakan masalah pencemaran udara bersumber dari penggunaaan bahan bakar fosil dan kegiatan perindustrian. Kegiatan industri mengemisikan berbagai macam pencemar udara, tergantung pada kegiatan industrinya.

Menurut Suyono (2014), sumber utama pencemaran udara adalah pembakaran bahan bakar untuk menghasilkan energi panas dan tenaga, biasanya berasal dari industri, komersial, dan rumah tangga; gas buang, debu, dan energi panas dari beberapa kawasan industri, termasuk pabrik kimia, peleburan besi/baja, industri semen dan keramik, aktivitas galian atau pertambangan, dan stasiun pembangkit listrik.
Zat pencemar melalui udara diklasifikasikan menjadi dua bagian yaitu partikel dan gas. Partikel adalah butiran halus yang masih mungkin terlihat dengan mata telanjang seperti uap air, debu, asap, kabut, dan fume. Sedangkan pencemaran berbentuk gas hanya dapat dirasakan melalui penciuman ataupun efek lokal akibat pajanan langsung. Gas-gas ini antara lain $\quad \mathrm{SO}_{2}, \quad \mathrm{NO}_{2}, \quad \mathrm{CO}, \quad \mathrm{CO}_{2}$, hidrokarbon, dan lain-lain (Perdana Gintings, 1998:56).

Menurut Suyono (2014) akibat pencemaran udara dapat mempengaruhi semua aspek kehidupan, baik terhadap manusia, flora, fauna, dan semua bahan yang ada di lingkungan kita. Pada manusia, pencemaran udara akan mempunyai potensi yang cukup besar terhadap gangguan fungsi saluran pernapasan. Sedangkan menurut Mukono (2008), gangguan kesehatan lainnya antara lain dapat berupa keluhan pada mata (mata terasa pedas dan berair), radang pada pernapasan, sembab paru, bronkitis menahun, emfisema, ataupun kelainan paru menahun lainnya.

Menurut Fardiaz (2010), sumber polusi yang utama berasal dari transportasi, dimana hampir $60 \%$ dari polutan yang dihasilkan terdiri dari karbon monoksida, dan sumber pencemar lainnya berasal dari proses industri. Sedangkan menurut Suyono (2014), CO dan $\mathrm{CO}_{2}$ dihasilkan oleh pembakaran BBM, batubara, dan sampah serta lahan/hutan; kegiatan rumah tangga dalam memasak menggunakan bahan 
bakar minyak, tungku pemanas menggunakan minyak, batubara, arang, atau kayu bakar; serta aktivitas merokok. Hasil pembakaran yang sempurna menghasilkan $\mathrm{CO}_{2}$ sedangkan hasil pembakaran yang tidak sempurna akan menghasilkan CO.

Pengertian karbon monoksida (CO) menurut Fardiaz (2010) adalah suatu komponen tidak berwarna, tidak berbau, mudah terbakar, dan bila terbakar menimbulkan nyala berwarna ungu kebiruan, terdapat dalam bentuk gas pada suhu di atas $192^{\circ}$ C. Sedangkan menurut Mukono (2008) karbon monoksida dapat memberikan kelainan pada tubuh yaitu memblokir fungsi transpor $\mathrm{HbO}_{2}$ dan meningkatkan $\mathrm{HbCO}$ dalam darah, serta menyebabkan kerusakan otot jantung dan susunan saraf pusat. Gejala keracunan karbon monoksida (CO) menurut Mukono (2008) antara lain, pusing, rasa tidak enak pada mata, telinga berdengung, mual, muntah, detak jantung meningkat, rasa tertekan di dada, kesulitan bernapas, kelemahan otototot, dan bisa meninggal dunia.

Berdasarkan

penelitian

Faradina Arifiyanti (2012), bahwa konsentrasi CO yang dihasilkan dari volume kendaraan yang melintas di persimpangan Jalan Jrakah Semarang lebih tinggi dibandingkan konsentrasi $\mathrm{CO}$ yang dihasilkan dari volume bahan bakar Marine Flue Oil (MFO) oleh pabrik besi. Sedangkan pada penelitian yang dilakukan Omri Sianturi pada tahun 2004, semakin besar konsentrasi karbon monoksida
(CO) di udara ambien diakibatkan oleh pertambahan jumlah kendaraan di ruas jalan. Dalam penelitian yang dilakukan oleh Niken Setyowaty (2014), bahwa angka konsentrasi CO tertinggi pada persimpangan Jalan Tanjungpura-Jalan Veteran yaitu menunjukkan angka sebesar 150.000 $\mu \mathrm{g} / \mathrm{Nm}^{3}$, dengan kadar $\mathrm{HbCO}$ responden sebesar 3,28\%. Hal tersebut menunjukkan bahwa adanya paparan gas $\mathrm{CO}$ di udara ambien berpengaruh terhadap kadar $\mathrm{HbCO}$ dalam darah manusia.

Dusun Demeling, Kelurahan Gedangan, Kecamatan Gedangan, Sidoarjo merupakan pemukiman penduduk yang terletak di antara padatnya lalu lintas Jalan Raya Gedangan dan dekat dengan pabrik minyak goreng. Keduanya adalah sumber pencemar dari emisi sumber bergerak dan emisi sumber tidak bergerak yang menghasilkan gas karbon monoksida (CO) di udara ambien yang berbahaya bagi kesehatan.

Jalan Raya Gedangan adalah bagian dari Jalan Ahmad Yani yang melintang mulai dari Kota Sidoarjo sampai Surabaya. Jalan Raya Gedangan menjadi salah satu ruas jalan utama yang penting bagi pertumbuhan kota Sidoarjo. Jalan Raya Gedangan terletak di sebelah timur pemukiman Dusun Demeling. Pembakaran bahan bakar kendaraan bermotor yang dihasilkan dari Jalan Raya Gedangan dapat mempengaruhi kadar gas CO di udara ambien. Sedangkan pabrik minyak goreng terletak di tengah pemukiman 
masyarakat Dusun Demeling Gedangan. Pabrik minyak goreng merupakan pabrik yang mengolah minyak kelapa sawit menjadi minyak goreng menggunakan bahan bakar batubara untuk menghasilkan uap bertekanan dalam proses produksinya. Dimana batubara mengandung unsur karbon (C) yang dapat menghasilkan karbon monoksida dari pembakaran yang tidak sempurna pada tekanan dan suhu tinggi. Akibat dari paparan gas karbon monoksida (CO) dapat mempengaruhi kemampuan hemoglobin mengikat oksigen dalam darah, sehingga akan meningkatkan kadar $\mathrm{HbCO}$ dalam darah. Oleh sebab itu, peneliti melakukan penelitian untuk mengetahui seberapa besar kadar $\mathrm{HbCO}$ dalam darah masyarakat akibat paparan gas CO yang berasal dari Jalan Raya Gedangan dan pabrik minyak goreng.

Berdasarkan uraian diatas peneliti tertarik untuk melaksanakan penelitian yang berjudul:

"GAMBARAN KADAR HbCO DALAM DARAH PADA MASYARAKAT TUSUN DEMELING, GEDANGAN, SIDOARJO".

\section{METODE PENELITIAN}

Jenis penelitian ini adalah penelitian deskriptif dengan pendekatan cross sectional.

Sampel yang diteliti adalah kadar HbCO dalam darah ibu rumah tangga yang berdomisili di Dusun Demeling dan kadar karbon monoksida (CO) di udara ambien sekitar Dusun Demeling yang meliputi wilayah yang dekat dengan Jalan Raya Gedangan dan wilayah yang dekat pabrik minyak goreng.

Teknik pengambilan sampel menggunakan teknik purposive sampling, yang didasarkan pada pertimbangan tertentu yang dibuat oleh peneliti (Notoatmodjo, 2010). Sampel HbCO dalam darah diambil sebanyak 12 sampel responden, dimana terdapat 6 titik yang masingmasing titik diambil 2 responden. Pengambilan sampel $\mathrm{HbCO}$ dilakukan 2 jam setelah pengukuran sampel CO di udara ambien. Sedangkan sampel gas karbon monoksida (CO) diambil sebanyak 5 titik, dimana 2 titik dekat dengan pabrik, 2 titik dekat dengan jalan raya, dan 1 titik diambil di tengahtengah keduanya.

Data hasil penelitian yang telah terkumpul, kemudian dianalisis menggunakan tabulasi secara deskriptif dalam bentuk tabel. 


\section{HASIL DAN PEMBAHASAN}

1. Hasil pemeriksaan kadar $\mathrm{HbCO}$

Tabel 1

Hasil Pemeriksaan kadar HbCO dalam Darah pada Masyarakat

Dusun Demeling Kecamatan Gedangan

\begin{tabular}{|c|c|c|c|}
\hline No. & Kode Sampel & Kadar HbCO $(\boldsymbol{\%})$ & Kriteria \\
\hline 1. & 1 & 11,82 & TM \\
\hline 2. & 2 & 10,63 & TM \\
\hline 3. & 3 & 5,24 & TM \\
\hline 4. & 4 & 12,32 & TM \\
\hline 5. & 5 & 8,25 & TM \\
\hline 6. & 6 & 11,65 & TM \\
\hline 7. & 7 & 9,45 & TM \\
\hline 8. & 8 & 4,56 & M \\
\hline 9. & 9 & 14,56 & TM \\
\hline 10 & 10 & 7,82 & TM \\
\hline 11. & 11 & 4,14 & M \\
\hline 12. & 12 & 11,58 & TM \\
\hline
\end{tabular}

Keterangan :

$\mathrm{M}=$ "Memenuhi syarat" jika kadar $\mathrm{HbCO} \leq 5 \%$

$\mathrm{TM}=$ "Tidak Memenuhi syarat" jika kadar $\mathrm{HbCO}>5 \%$

Berdasarkan Tabel 1 kadar $\mathrm{HbCO}$ dalam darah terendah adalah $4,14 \%$ dan yang tertinggi sebesar $14,56 \%$. Kriteria kadar $\mathrm{HbCO}$ dibagi dalam 2 tingkatan yaitu kadar $\mathrm{HbCO}$ $\leq 5 \%$ dikatakan normal atau "Memenuhi Syarat" dan dikatakan "Tidak Memenuhi Syarat" apabila kadar $\mathrm{HbCO}>5 \%$. Dari data yang telah diperoleh tersebut bila dibandingkan dengan kriteria di atas, maka sebagian besar $(83,33 \%)$ kadar HbCO dalam darah reponden Dusun Demeling Gedangan "Tidak Memenuhi Syarat".
Menurut Fardiaz (2010), faktor penting yang menentukan pengaruh CO terhadap tubuh adalah konsentrasi $\mathrm{HbCO}$ dalam darah, dimana semakin tinggi prosentase hemoglobin yang terikat oleh $\mathrm{CO}$ dalam bentuk $\mathrm{HbCO}$, maka semakin berpengaruh terhadap kesehatan manusia.

Menurut Agency for Toxic Substances and Disease Registry (2012),waktu tinggal karbon monoksida di dalam darah sekitar 68 jam. Jika orang yang telah menghirup CO dipindahkan ke udara 
yang bersih dan berada dalam keadaan istirahat, maka kadar $\mathrm{COHb}$ semula akan berkurang 50\% dalam waktu 4,5 jam dan selanjutnya sisa $\mathrm{COHb}$ akan berkurang $8-10 \%$ setiap jamnya.

2. Hasil pemeriksaan kadar $\mathrm{HbCO}$

Tabel 2

Hasil Pengukuran CO Udara Ambien di Sekitar

Dusun Demeling Kecamatan Gedangan

\begin{tabular}{|c|c|c|c|c|}
\hline No. & $\begin{array}{c}\text { Titik } \\
\text { Sampling }\end{array}$ & $\begin{array}{c}\text { Kecepatan } \\
\text { Angin }(\mathbf{m} / \mathbf{s})\end{array}$ & Kadar CO & $\begin{array}{c}\text { Baku Mutu } \\
\left(\mathbf{2 2 . 6 0 0} \boldsymbol{\mu g} / \mathbf{~ N m}^{\mathbf{3}}\right)\end{array}$ \\
\hline 1. & Titik 1 & $0,33-1,38$ & $6873,62 \mu \mathrm{g} / \mathrm{Nm}^{3}$ & $\mathrm{M}$ \\
\hline 2. & Titik 2 & $0,28-1,23$ & $16038,45 \mu \mathrm{g} / \mathrm{Nm}^{3}$ & $\mathrm{M}$ \\
\hline 3. & Titik 3 & $0,14-0,52$ & $1145,60 \mu \mathrm{g} / \mathrm{Nm}^{3}$ & $\mathrm{M}$ \\
\hline 4. & Titik 4 & $0,06-0,40$ & $1834,93 \mu \mathrm{g} / \mathrm{Nm}^{3}$ & $\mathrm{M}$ \\
\hline 5. & Titik 5 & $0,18-0,60$ & $2291,21 \mu \mathrm{g} / \mathrm{Nm}^{3}$ & $\mathrm{M}$ \\
\hline
\end{tabular}

Keterangan :

Titik 1: Area pinggir Jalan A. Yani No. 147 A Gedangan

Titik 2: Area pinggir Jalan A. Yani No. 147 C Gedangan

Titik 3: Di tengah pemukiman penduduk RT.01 RW.04 Dsn.Demeling

Titik 4: Pemukiman dekat pabrik RT.02 RW.04 Dsn.Demeling

Titik 5: Pemukiman dekat pabrik RT.03 RW.04 Dsn.Demeling

$\mathrm{M}=$ "Memenuhi" jika kadar CO kurang dari $22.600 \mu \mathrm{g} / \mathrm{Nm}^{3}$

$\mathrm{TM}=$ "Tidak Memenuhi" jika kadar CO lebih dari $22.600 \mu \mathrm{g} / \mathrm{Nm}^{3}$

Berdasarkan Tabel 2 kadar gas

CO di Dusun Demeling tertinggi sebesar $16038,45 \mu \mathrm{g} / \mathrm{Nm}^{3}$ dan kadar CO terendah sebesar 1145,60 $\mu \mathrm{g} / \mathrm{Nm}^{3}$, dimana hasil tertinggi diperoleh dari pengukuran sampel udara di dekat Jalan Raya Gedangan. Rata-rata kadar CO udara ambien di lokasi yang dekat dengan Jalan Raya Gedangan yaitu $11456,04 \mu \mathrm{g} / \mathrm{Nm}^{3}$, sedangkan rata-rata kadar $\mathrm{CO}$ udara ambien di lokasi yang dekat dengan pabrik minyak goreng 2063,07 $\mu \mathrm{g} / \mathrm{Nm}^{3}$. Berdasarkan Peraturan
Gubernur Jawa Timur nomor 10 tahun 2009 tentang Baku Mutu Udara Ambien dan Emisi Sumber Tidak Bergerak di Jawa Timur, baku mutu gas karbon monoksida (CO) adalah sebesar $22.600 \mu \mathrm{g} / \mathrm{Nm}^{3}$. Dari 5 titik pengukuran, semuanya hasil pengukuran kadar CO udara ambien sekitar Dusun Demeling memenuhi baku mutu.

Jalan Raya Gedangan merupakan jalan menjadi penghubung antara Kota Sidoarjo dengan kota-kota yang berada di 
sebelah utara dan barat Sidoarjo, seperti Surabaya, Mojokerto, dan sebagainya. Jalan raya Gedangan juga menjadi akses darat bagi pengguna jalan termasuk truk barang yang akan menuju Pulau Bali. Banyak kendaraan melintas pada Jalan raya Gedangan dapat berpengaruh terhadap meningkatnya kadar CO di udara, sehingga hasil pengukuran kadar $\mathrm{CO}$ di udara ambien pada titik tersebut tinggi. Di samping itu kecepatan angin juga menunjukkan angka tertinggi pada titik pengukuran di dekat jalan raya, hal tersebut dikarenakan banyak kendaraan yang melintas dengan kecepatan tinggi. Walaupun menurut Mulyanto, 2007 angin dapat mengurangi konsentrasi gas $\mathrm{CO}$ pada suatu tempat karena dipindahkan ke tempat lain, namun kadar CO di titik tersebut tinggi dikarenakan padatnya lalu lintas sehingga keberadaan CO di udara tetap pada kadar yang tinggi. Sedangkan hasil pengukuran $\mathrm{CO}$ terendah diperoleh dari pengukuran sampel udara di tengahtengah pemukiman penduduk, dimana kadar karbon monoksida (CO) dipengaruhi oleh kepadatan pemukiman, ketinggian cerobong pabrik, dan angin.

Apabila di bandingkan dengan hasil pemeriksaan kadar $\mathrm{HbCO}$ responden yang tinggi, tidak sebanding dengan hasil pemeriksaan kadar CO di udara ambien secara keseluruhan yang masih tergolong rendah. Hal tersebut disebabkan karena faktor lain, dimana kadar karbon monoksida (CO) dipengaruhi oleh kepadatan kendaraan, suhu, kelembaban, kecepatan angin, dan arah angin.

Pengambilan sampel dilakukan pada waktu pagi hari yakni pukul 09.00-10.00 WIB dalam keadaan cuaca cerah berawan, dengan suhu sebesar $32^{0} \mathrm{C}$, kelembaban sebesar 55\%-70\%, kecepatan angin tertinggi sebesar $1,38 \mathrm{~m} / \mathrm{s}$ dan kecepatan angin terendah sebesar $0,06 \mathrm{~m} / \mathrm{s}$, dan arah angin mengarah ke arah tenggara.

Kadar CO udara ambien di sekitar Dusun Demeling yang rendah disebabkan karena jumlah kendaraan yang rendah pada saat kegiatan sampling. Cuaca yang cerah berawan pada saat itu mengakibatkan suhu udara tinggi dan udara semakin renggang sehingga menyebabkan konsentrasi $\mathrm{CO}$ di udara menjadi semakin rendah. Pada kelembaban yang tinggi, kadar uap air dapat bereaksi dengan pencemar udara, sehingga menghasilkan zat lain yang tidak berbahaya atau menjadi zat pencemar sekunder, sehingga konsentrasi gas CO di udara ambien menjadi rendah. Rendahnya adar CO udara ambien dipengaruhi oleh kecepatan angin yang tinggi, karena sebaran polutan di udara menjadi luas sehingga kadar polutan menjadi rendah. Begitu pula dengan arah angin menentukan persebaran polutan di udara. Angin yang bergerak ke arah tenggara sejajar terhadap jalan sehingga polutan tersebut dapat menyebar secara cepat karena tidak ada gedung gedung yang menjadi penghalang. 
3. Umur Responden

Tabel 3

Distribusi Umur Responden Terhadap Kadar HbCO dalam Darah pada Masyarakat Dusun Demeling Gedangan

\begin{tabular}{|r|c|c|c|c|}
\hline No. & Umur & $\begin{array}{c}\text { Jumlah } \\
(\text { orang) }\end{array}$ & $\begin{array}{c}\text { Prosentase } \\
(\boldsymbol{\%})\end{array}$ & $\begin{array}{c}\text { Rata-rata Kadar HbCO } \\
\text { dalam darah }(\boldsymbol{\%})\end{array}$ \\
\hline 1. & $\leq 40$ tahun & 5 & 41,67 & $\begin{array}{c}6,24 \\
(4,14-9,45)\end{array}$ \\
\hline 2. & $>40$ tahun & 7 & 58,33 & $\begin{array}{c}11,54 \\
(8,25-14,56)\end{array}$ \\
\hline
\end{tabular}

Berdasarkan tabel 3 menunjukkan bahwa sebagian besar responden $(58,33 \%)$ memiliki umur $>40$ tahun, dapat dilihat pula bahwa pada kelompok umur tersebut memiliki rata-rata kadar $\mathrm{HbCO}$ sebesar $11,54 \%$, kadar tersebut lebih tinggi dibanding rata-rata kadar $\mathrm{HbCO}$ responden yang berumur $\leq 40$ tahun yakni sebesar 6,24\%, Jika dikaitkan dengan hasil pemeriksaan kadar $\mathrm{HbCO}$ dalam darah, sebagian besar responden yang berumur lebih dari 40 tahun memiliki kadar $\mathrm{HbCO}$ yang melebihi batas $5 \%$.

Disebutkan dalam penelitian Dewi N Khoiriyah (2016), bahwa karakteristik responden yaitu usia mempunyai hubungan dengan kadar $\mathrm{COHb}$ pada petugas Dishub dengan kekuatan korelasi (r) sedang yaitu 0.405. Sedangkan pada penelitian Novita Wulansari (2013), hasil penelitian menunjukkan bahwa ada hubungan antara umur dengan kadar $\mathrm{COHb}$ dalam darah ( $\mathrm{p}$ value = 0,029), dimana hal ini dapat diketahui bahwa semakin tua umur seseorang akan memiliki kadar
$\mathrm{COHb}$ lebih tinggi dibandingkan dengan yang lebih muda.

Menurut Siswanto (1994), umur seseorang merupakan salah satu faktor kerentanan individu, dimana terjadinya penurunan kapasitas kardiovaskuler karena proses menua dan berkurangnya fungsi elastisitas jaringan paru-paru sehingga kekuatan bernafas akan menjadi lebih sedikit.. Karena semakin tua seseorang akan semakin rentan terhadap paparan $\mathrm{CO}$, sehingga kadar $\mathrm{HbCO}$ akan semakin tinggi.

Berdasarkan hasil wawancara sebagian besar responden yang berusia lebih dari 40 tahun memiliki keluhan akibat paparan $\mathrm{CO}$, yaitu pusing dan pengelihatan terganggu. Menurut Mukono, 2008, gejala keracunan $\mathrm{CO}$ antara lain, pusing, rasa tidak enak pada mata, telinga berdengung, mual, muntah, detak jantun meningkat, rasa tertekan di dada, kesukaran bernapas, kelemahan otot-otot, tidak sadar, dan bisa meninggal dunia. 
4. Lama Bermukim Responden

Tabel 4

Distribusi Lama Bermukim Responden terhadap Kadar HbCO dalam Darah pada Masyarakat Dusun Demeling Gedangan

\begin{tabular}{|c|c|c|c|c|}
\hline No. & $\begin{array}{c}\text { Lama } \\
\text { Bermukim }\end{array}$ & $\begin{array}{c}\text { Jumlah } \\
(\text { orang) }\end{array}$ & $\begin{array}{c}\text { Prosentase } \\
(\boldsymbol{\%})\end{array}$ & $\begin{array}{c}\text { Rata-rata Kadar HbCO } \\
\text { dalam darah }(\boldsymbol{\%})\end{array}$ \\
\hline 1. & $\leq 5$ tahun & 0 & 0 & - \\
\hline 2. & $>5$ tahun & 12 & 100 & $\begin{array}{c}9,34 \\
(4,14-14,56)\end{array}$ \\
\hline
\end{tabular}

Berdasarkan tabel 4 dari 12 responden bahwa lama bermukim seluruh responden (100\%) yaitu lebih dari 5 tahun dengan rata-rata kadar $\mathrm{HbCO}$ dalam darah responden yaitu 9,34\%. Kesibukan responden adalah sebagai ibu rumah tangga, dimana sebagian besar aktifitasnya dilakukan di dalam rumah, sedangkan sebagian kecil aktifitas yang dilakukan di luar rumah dalam kisaran waktu 1-6 jam. Pada kasus pencemaran gas karbon monoksida, lama bermukim seseorang tidak mempengaruhi besar paparan yang diterima, hal tersebut ditunjukkan pada hasil pemeriksaan sampel darah responden dimana kadar $\mathrm{HbCO}$ beragam pada semua responden yang bermukim lebih dari 5 tahun. Hal tersebut sesuai hasil penelitian Dewi N Khoiriyah (2016) yang menunjukkan tidak ada hubungan antara lama paparan dengan kadar $\mathrm{COHb}$ petugas Dishub. Besar kecilnya kadar $\mathrm{HbCO}$ bisa disebabkan oleh faktor lain yang tidak diteliti, misalnya aktivitas luar rumah yang dilakukan oleh responden dan sistem pertahanan tubuh atau kekebalan seseorang.

5. lokasi Tinggal Responden

Tabel 5

Distribusi Lokasi Tinggal Responden terhadap Kadar HbCO dalam Darah pada Masyarakat Dusun Demeling Gedangan

\begin{tabular}{|c|c|c|c|c|c|}
\hline No. & Lokasi Tinggal & $\begin{array}{c}\text { Jumlah } \\
(\text { orang) }\end{array}$ & $\begin{array}{c}\text { Kadar } \\
\mathbf{H b C O} \leq \\
\mathbf{5 \%}\end{array}$ & $\begin{array}{c}\text { Kadar } \\
\mathbf{H b C O} \\
\mathbf{5 \%}\end{array}$ & $\begin{array}{c}\text { Rata-rata Kadar } \\
\text { HbCO dalam } \\
\text { darah (\%) }\end{array}$ \\
\hline 1. & $\begin{array}{c}\text { Dekat dengan Jalan } \\
\text { Raya Gedangan }\end{array}$ & 6 & 0 & 6 orang \\
$(0 \%)$ & $(100 \%)$ & $\begin{array}{c}9,98 \\
(5,24-12,32)\end{array}$ \\
\hline 2. & $\begin{array}{c}\text { Dekat dengan pabrik } \\
\text { minyak goreng }\end{array}$ & 6 & $\begin{array}{c}2 \text { orang } \\
(33,33 \%)\end{array}$ & $\begin{array}{c}4 \text { orang } \\
(66,67 \%)\end{array}$ & $\begin{array}{c}8,68 \\
(4,14-14,56)\end{array}$ \\
\hline
\end{tabular}


Berdasarkan hasil kuisioner seperti yang tercantum pada tabel IV.5 diketahui bahwa terdapat 50\% responden yang lokasi tempat tinggalnya dekat dengan pabrik dan $50 \%$ responden lokasi tinggalnya dekat dengan jalan raya. Penyebaran gas CO di udara tergantung pada keadaan lingkungan, untuk daerah perkotaan yang banyak kegiatan industrinya dan lalu lintasnya padat. Sehingga seseorang yang tinggal dekat dengan jalan raya dan pabrik sangat berpotensi terhadap paparan gas $\mathrm{CO}$ sehingga dapat mempengaruhi kadar $\mathrm{HbCO}$ seseorang. Prosentase kadar $\mathrm{HbCO}$ dalam darah masyarakat yang lokasi tinggalnya dekat dengan Jalan Raya Gedangan lebih tinggi dibandingkan dengan masyarakat yang lokasi tinggalnya dekat dengan pabrik minyak goreng. Rata-rata kadar $\mathrm{HbCO}$ dalam darah responden yang dekat dengan Jalan Raya Gedangan adalah 9,98\%, sedangkan rata-rata kadar $\mathrm{HbCO}$ dalam darah responden yang dekat dengan pabrik minyak goreng yaitu $8,68 \%$.

Hasil penelitian Kuuni Ulfah (2016), menunjukkan bahwa rata-rata kadar gas CO di tepi jalan lebih tinggi 2,36 kali dibandingkan bukan tepi jalan. Sedangkan rata-rata kadar $\mathrm{HbCO}$ pedagang tepi juga lebih tinggi dibanding bukan tepi jalan dan semua pedagang di tepi jalan memiliki HbCO melebihi batas Biological Exposure Indices.

Lokasi tinggal responden berpengaruh terhadap kadar $\mathrm{HbCO}$ dalam darah, dimana tingginya kadar
$\mathrm{HbCO}$ berpengaruh dengan tingginya paparan gas $\mathrm{CO}$ yang berasal dari hasil pembakaran bahan bakar kendaraan bermotor di jalan raya. Hasil produk yang tinggi dikarenakan padatnya lalu lintas kendaraan. Berat jenis gas CO lebih ringan sehingga gas $\mathrm{CO}$ berada di zona pernafasan. Aktivitas kendaraan bermotor di jalan raya berlangsung selama 24 jam.

Sedangkan prosentase kadar $\mathrm{HbCO}$ dalam darah masyarakat yang lokasi tinggalnya dekat dengan pabrik lebih rendah daripada yang tinggal dekat dengan jalan raya, disebabkan karena cerobong pabrik yang tinggi, sehingga pola penyebaran gas $\mathrm{CO}$ masih harus melalui beberapa faktor yang dapat mengakibatkan kadar CO menjadi rendah. Terlebih durasi paparan dari pabrik lebih kecil karena proses produksi tidak berjalan terusmenerus selama 24 jam melainkan terbagi dalam beberapa jam kerja.

\section{KESIMPULAN DAN SARAN Keseimpulan}

1. Kadar HbCO dalam darah pada responden Dusun Demeling yang tinggal dekat dengan Jalan Raya Gedangan memiliki rata-rata sebesar $9,98 \%$ dan responden yang tinggal dekat dengan pabrik minyak goreng memiliki rata-rata sebesar 8,68\%.

2. Kadar karbon monoksida (CO) udara ambien sekitar Dusun Demeling pada lokasi yang dekat dengan Jalan Raya Gedangan memiliki rata-rata sebesar 
$11456,04 \mu \mathrm{g} / \mathrm{Nm}^{3}$ dan pada lokasi yang dekat dengan pabrik minyak goreng memiliki rata-rata sebesar 2063,07 $\mu \mathrm{g} / \mathrm{Nm}^{3}$.

3. Umur responden $>40$ tahun memiliki rata-rata kadar $\mathrm{HbCO}$ dalam darah sebesar $11,54 \%$ dan responden berumur $\leq 40$ tahun memiliki rata-rata kadar $\mathrm{HbCO}$ dalam darah sebesar 6,24\%.

4. Lama bermukim semua reponden adalah $>5$ tahun dengan rata-rata kadar $\mathrm{HbCO}$ dalam darah sebesar $9,34 \%$.

5. Lokasi tinggal di dekat Jalan Raya Gedangan dengan rata-rata kadar $\mathrm{HbCO}$ dalam darah responden sebesar 9,98\% dan lokasi tinggal di dekat pabrik minyak goreng dengan rata-rata kadar $\mathrm{HbCO}$ dalam darah responden sebesar $8,68 \%$.

\section{Saran}

1. Untuk menguragi kadar $\mathrm{CO}$ di udara ambien, masyarakat diharapkan agar dapat menciptakan upaya sadar lingkungan dengan cara menanam tanaman hijau di sekitar rumah.

2. Untuk mengurangi efek kesehatan akibat paparan $\mathrm{CO}$ diharapkan masyarakat rajin berolahraga dan memperhatikan asupan gizi agar dapat mendukung daya tahan tubuh.

3. Untuk peneliti selanjutnya diharapkan dapat mengembangkan penelitian tentang kadar $\mathrm{HbCO}$ yang dikaitkan dengan faktor-faktor yang mempengaruhi kadar $\mathrm{HbCO}$, misalnya jenis bahan bakar kendaraan yang menghasilkan $\mathrm{CO}$, jenis kendaraan berdasarkan usia kendaraan, atau aktifitas responden yang mempengaruhi penurunan kadar $\mathrm{HbCO}$.

\section{DAFTAR PUSTAKA}

Achmad, Rukaesih, 2004. Kimia Lingkungan. Yogyakarta, Andi.

Agency for Toxic Substances and

Disease Registry, 2012.

Toxicological Profile for Carbon

Monoxide. Georgia: U.S.

Department Of Health And

Human Services.

Arifiyanti, Faradina; Sudarno; \&

Dwi Siwi Handayani, 2012.

Pengaruh Kelembaban, Suhu,

Arah Dan Kecepatan Angin

Terhadap Konsentrasi Karbon

Monoksida (Co) Dengan

Membandingkan Dua Volume

Sumber Pencemar Di Area

Pabrik Dan Di Persimpangan

Jalan (Studi Kasus: PT. Inti

General Yaja Steel dan

Persimpangan Jrakah). Skripsi:

Prodi Teknik Lingkungan,

Fakultas Teknik Universitas

Diponegoro.

Arya Wardhana, Wisnu, 2004.

Dampak

Pencemaran

Lingkungan. Yogyakarta, Andi.

Austin, G. T., 1996. Industri Proses

Kimia. Jilid 1. Edisi Kelima.

Jakarta, Penerbit Erlangga.

Faisal F, Yunus F, \& Harahap F, 2012. Dampak Asap Kebakaran Hutan pada Pernafasan. Cermin Dunia Kedokteran. 38 (1): 31-5. 
Fardiaz, S, 2010. Polusi Air dan Udara. Yogyakarta, Kanisius.

Gintings, Perdana, 1988. Mencegah dan Mengendalikan Pencemaran Industri. Jakarta, Sinar harapan.

Keputusan Menteri Lingkungan

Hidup R.I Nomor: Kep02/MENKLH/1/1998 Tentang Pedoman Penetapan Baku Mutu Lingkungan.

Khoiriyah, Dewi N, 2016. Hubungan Lama Paparan dan Kadar CO Lingkungan dengan Kadar $\mathrm{COHb}$ dalam Darah Petugas Dinas Perhubungan

Terminal Tirtona. Thesis, Universitas Sebelas Maret.

Notoatmodjo, S, 2010. Metodologi Penelitian Kesehatan. Jakarta, Rineka Cipta.

Mukono, H.J, 2008. Pencemaran Udara dan Pengaruhnya Terhadap Gangguan Saluran Pernapasan. Surabaya, Airlangga University Press. , H.J, 2011. Prinsip Dasar

Kesehatan Lingkungan.

Surabaya, Airlangga University Press, Edisi Kedua.

Mulyanto, H.R, 2007. Ilmu Lingkungan. Yogyakarta, Graha Ilmu.

Peraturan Pemerintah RI Nomor 41 Tahun 1999 tentang Pengendalian Pencemaran Udara.

Peraturan Menteri Tenaga Kerja dan Transmigrasi No. PER.13/MEN/ X/2011 Tentang Nilai Ambang Batas Faktor Fisika dan Faktor Kimia di Tempat Kerja.
Prastyo, Gunawan Eko, 2016. Gas Karbon Monoksida. https:// civitas.uns.ac.id/gunawanhse/20 16/12/15/gas-karbonmonoksida/. Diakses pada 21 Juli 2017.

Rivanda, Andrian, 2015. Pengaruh Paparan Karbon Monoksida Terhadap Daya Konduksi Trakea. Bandar Lampung, Fakultas Kedokteran, Universitas Lampung, Majority, 4 (8).

Sentra Informasi Keracunan Nasional, 2010. Carbon Monoxide. Jakarta, Badan Pengawasan Obat dan Makanan.

Setyowaty, Niken; Agus Fitriangga; \& Dian Rahayu, 2014. Potensi Gangguan Kesehatan Polisi Lalu Lintas Akibat Karbon Monoksida (CO). Skripsi: Prodi Teknik Lingkungan, Universitas Tanjungpura Pontianak.

Sianturi, Omri. 2004. Evaluasi Emisi Karbon Monoksida dan Partikel Halus dari Kendaraan Bermotor di Kota Semarang. Tesis. Semarang: Universitas Diponegoro.

Siswanto, A, 1994. Toksikologi Industri. Balai Hiperkes Jawa Timur.

Sitepoe, Mangku, 1997. Usaha Mencegah Pencemaran Udara. Jakarta, Gramedia Widiasarana Indonesia.

SNI 19-7119.6-2005 tentang Udara ambien - Bagian 6: Penentuan lokasi pengambilan contoh uji pemantauan kualitas udara ambien. 
Soekamto, T.H dan David, S.P, 2012. Intoksikasi Karbon Monoksida. Universitas Airlangga Surabaya. Jurnal Kedokteran. Vol.1-No.1. (http://journal.unair.ac.id/downl oadfull/RE42671c12a97c05fulla bstract.pdf). Diakses pada: 29 Januari 2017.

Suharto, Ign, 2011. Limbah Kimia dalam Pencemaran Udara dan Air. Yogyakarta, Andi.

Sukandarrumidi, 2006. Batubara dan Pemanfaatannya. Yogyakarta, Gadjah Mada University Press.

Suyono, 2014. Pencemaran Kesehatan Ligkungan. Jakarta, EGC.

Theriault GP, 1995. Cardiovascular Disorders. Occupational Disorders by System. In: Levy BS, Wegman DH. Editors. Occupational Recognizing Preventing Work-related Disease. 3rd ed. Boston: Little, Brown and Co: 563-66.

Ulfah, Kuuni, 2016. Perbedaan Antara Kadar Gas CO, Kadar
Karboksihemoglobin (Hbco) dan Tekanan Darah Pedagang Tepi Jalan dengan Bukan Tepi Jalan di Surabaya. Thesis, Universitas Airlangga.

Wichaksana, A, Astono, \& Hanum, K, 2002. Dampak Keracunan Gas Karbon Monoksida Bagi Kesehatan Pekerja. Jakarta, Cermin Dunia Kedokteran No. 136.

WHO, 2004. Carbon Monoxide Environmental Health Criteria. Geneva, World Health Organization.

Wulansari, Novita, 2013. Faktor Faktor Risiko Paparan Gas CO Terhadap Kadar Hbco dalam Darah pada Mahasiswa Fakultas Kesehatan Udinus Semarang Tahun 2013. Skripsi, Program Studi Kesehatan Masyarakat, Fakultas Kesehatan, Universitas Dian Nuswantoro Semarang. 